УДК 811.111
DOI 10.35433/philology.1(89).2019.56-62

Н. М. Дяченко,

кандидат філологічних наук, доцент

(Житомирський державний університет імені Івана Франка)

dyachenkonatali@gmail.com

ORCID: 0000-0002-6131-077X

В. В. Халін,

кандидат педагогічних наук, доцент

(Житомирський державний університет імені Івана Франка)

d.phil.jouregmail.com

ORCID: 0000-0003-4967-1721

\title{
КОМУНІКАТИВНІ СТРАТЕГІЇ В СУЧАСНОМУ УКРАЇНСЬКОМУ ПОЛІТИЧНОМУ ДИСКУРСІ
}

У статті представлений матеріал про комунікативні стратегії сучасного украӥнського політичного дискурсу (на прикладі політичної риторики кандидатів на посаду Президента Украӥни П. Пороченка та

В. Зеленського). Зокрема розглянута сутність поняття "політичний дискурс" у комунікативній лінгвістииі, схарактеризовані основні комунікативні стратегії й тактики політичного дискурсу, а також специифіка використання мовних засобів, які в сукупності забезпечують втілення обраних комунікативних стратегій і тактик у промовах політиків.

Ключові слова: політичний дискурс, комунікативна стратегія, комунікативна тактика, П. Порошенко, В. Зеленський.

Постановка проблеми. Політика як особлива сфера діяльності людини посідає одне з чільних місць у житті сучасного суспільства. Політична риторика є одним із засобів боротьби за владу й гармонізації суспільних відносин шляхом подолання соціальних конфліктів силою слова. Характер політичного спілкування зумовлює наявність двох протилежних сторін, за якої роль адресата найчастіше належить народу, а роль адресанта - політикові, державному діячеві.

Комунікація в межах політичного дискурсу відбувається в певному ситуативному контексті й спрямована на здійснення конкретних прагматичних інтенцій шляхом використання вербальних i невербальних засобів виразності. Політичний дискурс є відображенням суспільно-політичного життя країни, носієм елементів іiі культури, загальних, національно специфічних та інституційних цінностей. За висловленням Р. Шварценберга, політична комунікація для політичної системи - "це те саме, що кровообіг для організму людини", тому актуальність нашого дослідження зумовлена необхідністю всебічного грунтовного аналізу сучасного політичного дискурсу, зокрема й на рівні вивчення ідіостилю політичних лідерів та їхнього комунікативно-стратегічного потенціалу.

Аналіз останніх досліджень із теми. Останнім часом окремі проблеми політичного дискурсу стали об'єктами обговорення в науковій і публіцистичній літературі. Категорії дискурсу загалом і політичного зокрема присвятили свої праці Ф. С. Бацевич, Т. М. Ващук, І. Ю. Вільчинська, В. П. Горбатенко, Н. В. Кондратенко, К. Я. Кусько, В.А.Підгрушний, О. Й. Шейгал, О. В. Яшенкова та ін. Про те, наскільки значимою стала політика й політична комунікація, свідчить і поява окремої галузі - політичної лінгвістики - дисципліни, яка розвинулася на перетині політології та мовознавства і яка досліджує закономірності й механізми взаємовпливу і взаємозв'язку між мовою, мисленням, комунікацією, політичними суб'єктами й політичною свідомістю суспільства, щоб створити умови для вироблення ефективних стратегій і тактик політичної діяльності. А оскільки мова - це важливий елемент політичної діяльності, необхідний для впливу, керування життям країни, суспільством і світоглядом громадян, то планування мовних дій політика, спрямоване на досягнення поставлених цілей, його мовну комунікацію можна вважати стратегічним процесом, котрий реалізується через конкретні комунікативні тактики.

У світлі останніх подій у суспільно-політичному житті нашої країни, коли топ-темою дискусій наприкінці 2018 - на початку 2019 рр. стали вибори Президента України, особливої актуальності набуває вміння ефективної взаємодії під час політичної комунікації, тому що дискурсивна діяльність у цій царині значною мірою зумовлена рівнем загальної комунікативної грамотності й культури та часто вимагає значних зусиль для толерантного ставлення до партнерів по комунікації, аби мінімалізувати іiі негативний вплив на суспільство щонайменше в довгостроковій перспективі.

Мета статті - дослідити специфіку використання комунікативних стратегій і тактик у сучасному українському політичному дискурсі (на прикладі політичної риторики кандидатів на посаду Президента України П. Порошенка та В. Зеленського).

Виклад основного матеріалу. Політичний дискурс - це політична комунікація, учасниками якої виступають сторони суспільно-політичних відносин. Вона поєднує в собі інформацію 3 конкретними 
прагматичними цілями, тобто політична комунікація завжди має інтенційний характер. Головна інтенція цього типу дискурсу - боротьба за владу, а тому мовлення сприймається як боротьба, головна мета якої змагання та перемога.

Якщо політику вважати боротьбою за утримання й захоплення влади, політичний дискурс $\epsilon$ демонстрацією цієї боротьби. I тому, "розуміння політичного дискурсу передбачає знання фону, очікувань автора й аудиторії, прихованих мотивів, сюжетних схем і улюблених логічних переходів, що існують у конкретну епоху" [4: 118].

Учасниками політичного дискурсу є адресат - соціум (народ, партійні прихильники), адресант політик, лідер політичної партії, президент, державний діяч [6: 114-121].

Політичний дискурс має свої жанри. Він може існувати як у писемній, так і в усній формі. До писемної форми політичного дискурсу належать різні документи: угоди, партійні програми, маніфести, політичні листівки та плакати, рубрики політичних новин у пресі, блоги політиків у мережі Інтернет. До усної форми політичного дискурсу зараховують публічні виступи політиків, їхні виступи на радіо, по телебаченню, інтерв’ю, прес-конференції, парламентські дебати, теле- та радіоновини.

Політичні діячі активно використовують виступи в різних сферах своєї діяльності, тому за місцем реалізації (вибори, парламент, офіційні зустрічі, дебати тощо) вирізняють парламентський (він регламентується особливими вимогами), передвиборний, партійний, привітальний, святковий (присвячений пам'яті когось) виступи [6: 195-199]. Часто така комунікація зорієнтована на масову аудиторію, до якої звертаються за допомогою засобів масової інформації, зокрема до Інтернет-мережі, яку політики тривалий час ігнорували. Нині майже кожний політичний діяч має персональну сторінку в соціальних мережах, блог чи канал, де вони розміщують свої передвиборчі програми, спілкуються 3 виборцями, що робить їх популярними та ближчими до народу.

Основою політичної комунікації є політичний текст. Це інструмент боротьби за владу сил та інтересів, які конфліктують між собою. Діапазон політичний текстів досить широкий, але спільне в них те, що всі вони є формою для представлення народу своїх політичних мотивів і цілей відповідно до головної мети політики - здобуття та утримання влади.

Тип комунікації політичного дискурсу - змішаний, адже він являє собою письмово підготовлений текст і усну промову в тісній контактній єдності. За своєю природою політичний дискурс $\epsilon$ монологічним, але в ньому наявні й елементи діалогу. Провідною його особливістю є колективний характер, адже він репрезентує інтереси групи політиків, адресат мовлення лише висвітлює їх у промові. Тому політичний текст зазвичай представлений двома й більше індивідами, тобто власне автор (спічрайтер), який завжди $є$ анонімним, і політик, який озвучує текст і якому офіційно приписують авторство [6: 199-205].

Для того, щоб комунікативний акт політичного дискурсу був ефективним та успішним, адресат повинен належно підготуватися. "Щоб виступ мав успіх, добре сприймався аудиторією, необхідно його оригінально побудувати" [7:50]. Кожен політичний діяч усвідомлює необхідність правильного компонування, розташування мовних одиниць, тобто всього того, що являє собою суть і специфіку побудови промови. Тому в основі політичного тексту лежить трихотомічна система античної риторики (вступ, основна частина і висновок), кожен елемент якої виконує свої функції.

3 погляду мовної структури, на синтаксичному рівні сучасні політики для побудови текстів своїх промов найчастіше використовують прості речення, адже вони легше сприймаються і мають більший вплив на слухачів. Таке спрощення зумовлене загальними тенденціями розвитку мови і впливом на нього 3МI, мови реклами [6:202]. Також широко вживаються питальні та умовні речення, що пояснюється дебатним характером виступів.

Лексика політичних промов складається із загальновживаних літературних слів, доступних усім присутнім адресатам. Полемічність політичного дискурсу впливає на добір лексики й зумовлює певну театралізацію останньої, а також передбачає наявність різних цінностей та оцінок, створення негативного образу політичного опонента [2: 5]. Політики використовують слова-гасла та ключові слова, щоб викликати в слухачів очікувану реакцію, саме за допомогою них оратор подає інформацію із простотою у вираженні складного.

Отже, найважливішою функцією політичного дискурсу $є$ функція політичної пропаганди, переконання та впливу. Мовне маніпулювання політичною свідомістю в політичному дискурсі здійснюється за допомогою способів і засобів побудови промови, використання слів-гасел, ключових слів, мовно-риторичних особливостей та вдало дібраних комунікативних стратегій і тактик.

Людське спілкування базується на плануванні мовленнєвих дій та виборі оптимального способу досягнення цілей комунікантів. "Кожен конкретний крок реалізується, як правило, через різні заходи та дії, які можуть розтягнутися на значний відрізок часу" [6:321]. Тобто комунікацію можна назвати стратегічним процесом, який забезпечується через конкретні комунікативні стратегії. 
Як зазначає О. Яшенкова, комунікативна стратегія - це "головна лінія мовленнєвої поведінки в межах конкретної комунікативної події, що визначається загальною метою комунікації, ситуативним контекстом і уявленнями про адресата" [7: 156].

Досягнення поставленої мети й реалізація комунікативної стратегії здійснюється завдяки тактикам. 3 одного боку, тактика - шлях реалізації стратегії, а з іншого боку, спосіб мовленнєвого впливу, сукупність мовленнєвих засобів. У межах однієї стратегії зазвичай виокремлюють кілька мовленнєвих тактик, які відрізняються залежно від типу дискурсу, мети адресанта, мовленнєвого жанру тощо.

Сучасні науковці виокремлюють низку різноманітних комунікативних стратегій в політичному дискурсі. О.Яшенкова виділяє різновиди стратегій відповідно до жанрів політичного дискурсу та конфігурації інтенцій у конкретного суб'єкта дискурсу в певній ситуації. У ії класифікації виокремлені такі стратегії: самопрезентації, агітаційна (тактики обіцянки, застереження, надання оцінного значення, протиставлення, наведення аргументів "за", запрошення, прямого спонукання, апелювання до авторитету, апелювання до моральних цінностей тощя), формування емоційного настрою, інформаційно-інтерпретаційна (тактики визнання існування проблеми, акцентування на позитивній інформації, пояснення, коментування, розгляду проблеми під новим кутом, вказування на шлях розв'язання проблеми), аргументативна, маніпулювання (тактики навішування ярликів, гіперболізацію, применшення, спрощееня понять, замовчування, підтасовку $i$ фабрикацію фактів, посилання на авторитети тощзо), дискредитації (тактика акиентування на негативних якостях опонента або вказування на помилки опонента), нападу (тактики звинувачення та образи), самозахисту (тактики переадресації удару або превентивного нападу) та інші [докладніше див.: 7: 162-170].

Інший підхід до систематизації політичних стратегій мають О. Семенюк та В. Паращук, які поділили їх відповідно до наявності адресата-спостерігача, котрим виступає потенційний виборець:

Стратегія "гра на зниження", яка спрямована на суперника, щодо демаскування та викриття його позицій. Ця стратегія представлена такими тактиками [6:199-200]: аналіз-"мінус", тактика (безособового) звинувачення, тактика викриття, тактика образи.

Стратегія "гра на підвищення" характеризується бажанням мовця виставити себе у вигідному світлі, збільшити свою значимість в очах електорату, підвищити свій авторитет. До ії тактик належать [6: 200]: тактика аналіз-"плюс", тактика самопрезентації, тактика відведення критики, тактика самовиправдання.

Стратегія театральності особливо чітко проявляється в передвиборчих перегонах, під час виступів політиків перед аудиторією, на кшталт виступу актора перед публікою на сцені в театрі, що змушує політика вдаватися до дещо перебільшеної риторики, при чому мовець намагається (навіть за наявності безпосереднього (прямого) опонента) вплинути на картину світу не свого противника, а свого електорату. Стратегія реалізується через такі тактики [6: 200-201]: тактика підбурювання, тактика кооперації, тактика інформування, тактика обіцянки, тактика провокації.

С. Абрамович розрізняє дві основні тактики мовленнєвого впливу: пряму та непряму. При застосуванні непрямої тактики "комунікант не вносить до своїх тверджень прихованого смислу - мається на увазі лише те, що сказано, і нічого більше" [1:294]. Використання непрямої тактики передбачає завуальований зміст висловлювання співрозмовника, який за допомогою певних прийомів говорить те, про що не може сказати прямо.

Найважливішим інструментом впливу політика на людей вважають мову й невербальні засоби, які в сукупності забезпечують втілення його комунікативних стратегій і тактик. Завершальна мета їхнього використання - це модифікація поглядів, свідомості адресата на користь адресанта або для їхньої взаємної вигоди. Залежно від наміру політичного діяча (чи то завоювання влади в результаті вдало проведеної передвиборчої кампанії, чи то утримання влади 3 поясненням ефективності роботи іiі інституцій), обираються ефективні комунікативні стратегії й тактики, котрі реалізуються у виборі мовцем комунікативних дій. На вибір конкретної стратегії промови впливають такі фактори, як мета промови, комунікативні настанови та характер взаємодії зі слухачем.

Мовна особистість політика реалізується у відповідній тактико-стратегічній парадигмі, що включає наявність комплексу різнорівневих мовних засобів, які необхідні для складання текстів. І хоча тексти для публічного виступу політика зазвичай пишуть спеціально навчені фахівці - спічрайтери, - які контролюють правильність побудови ораторської промови, їі точність, лаконічність і ясність, не лише грамотно структурований текст політичного виступу впливає на слухачів. Успішному політичному діячеві слід мати запаси знань із риторики, лінгвістики та психології, які допоможуть ефективно створити, подати текст і справити бажаний ефект на аудиторію.

Аналізуючи комунікативну поведінку в передвиборчій кампанії можна простежити дотримання кандидатами стратегії публічності та уникнення публічності, які демонструють відповідно П. Порошенко та В.Зеленський. У свідомості виборців вони є представниками двох різних світів, починаючи від обрання мовного коду: П. Порошенко обирає для спілкування в межах держави українську, зрідка переходячи на російську, а з представниками інших держав - англійську мову, а для В. Зеленського звичним засобом комунікації є російська мова. Протиставлення відбувається у таких площинах: стара 
політична еліта - нове обличчя; людина без політичного досвіду, представник олігархату - людина 3 народу; головнокомандувач - цивільна особа, яка ніколи не перебувала в лавах армії; проєвропейські погляди - проросійське світобачення. І цей перелік можна продовжувати далі.

На думку багатьох спостерігачів цього політичного двобою, обидві сторони максимально використали електоральні настрої для побудови стратегічних ліній своєї поведінки. П. Порошенко зосередився на розкаянні в помилках, прагненні закріпити й примножити здобутки, зіграти на почутті страху втратити те, що далося українському народові дуже дорогою ціною, та акцентуванні на недоліках суперника. В. Зеленський діяв у межах стратегії десакралізації влади, спираючись на тези про необхідність усунення в державі корупції, швидке закінчення війни й подолання бідності. Упродовж перегонів виборці мали змогу аналізувати світоглядні пріоритети опонентів, втілені в їхніх політичних гаслах. Застосовуючи агітаційну стратегію, П. Порошенко використав тактики апелювання до моральних цінностей - це курс на автентичність, проєвропейський вектор розвитку: "Армія! Мова! Bipa! Геть від Москви!", "Ми йдемо своїм шляхом"; тактики протиставлення, яка реалізується в демонстрації своїх переваг: "Реальні справи, а не брехливі обіиянки!", "Кандидатів багато - президент один"; апеляція і до розуму ("Думай"), і до почуттів виборців (скандальні плакати із зображеннями П. Порошенка i В. Путіна); бажання привернути увагу молодіжної аудиторії: "Додай драйву! Андеграунд з тобою!!!". В. Зеленський для успішної агітаційної кампанії використовував стратегію формування емоційного настрою, зокрема тактику розгляду проблеми під новим кутом - насамперед це увага до пріоритетів "маленької" людини "Президент - слуга народу"; акцент на молоді: "Все буде Зе!шибісь!"; тактику прямого спонукання, у якому реалізується одна 3 головних ідей - десакралізація влади: "Зробимо $\ddot{x}$ разом"; тактику обіцянки: "Весна прийде - саджати будемо", "Весна покаже, хто де крав" (хоча прямих обіцянок він прагне не декларувати "Ні обічянок, ні пробачень").

Відомо, що передвиборча кампанія - це період сплеску емоцій, значної, часто невиправданої експресивності, якої припускаються конкуренти у своїх висловлюваннях. 3 огляду на два типи взаємин у політичному дискурсі, які виділяє А. Михальська - агональний (зосереджений на суперництві та перемозі) і гармонізуючий (в основу якого закладено істину й згоду) [4] - формат передвиборчої кампанії передбачає саме перший тип взаємодії між суперниками. Тому в мовленні політиків $\epsilon$ лексику, спрямована на приниження та образу адресата (тактика образи). Часто такі зневажливі слова демонструють емоції мовця, які не підкріплюються доказами проти звинувачуваного. На жаль, опоненти не соромиться називати свого опонента лайливими словами. Цитати цих виступів швидко поширюються через Інтернет. Вульгарні слова є своєрідними маркерами, що характеризують розумову діяльність, зовнішній вигляд або поведінку адресата. I оскільки постаті обох кандидатів на найвищу посаду неоднозначні як серед колег-політиків, так і в народі, кожен із них здобув цілу низку прізвиськ переважно виразної негативної конотації: П. Порошенко - Порох, ПеПе, иоколадний заєць, Шоколадний, Шоколадний Петя, Вальиман, барига, Пєия та інші; В. Зеленський - Зе, слуга народу, слуга урода, преЗедент, ЗеВова, блаЗень, клоун, маріонетка Коломойського, наркоман, кіт у мішку, голограма, зеля, ВАЗ, ваЗелін, артикль та ін.

Простеживши за діяльністю кандидатів, можна відзначити, що П. Порошенко виявив значну активність упродовж агітаційної кампанії перед другим туром. Практично щодня суспільство мало змогу спостерігати його виступи на різних майданчиках, у мережі публікувалися нові записи, оприлюднювалися відео. Участь у різних телепрограмах привертала увагу аудиторії кандидата, справляючи вплив на рейтинги як каналу, програми, так і самого політика. 3 огляду на високий рівень недовіри, продемонстрований у першому турі, народний обранець намагався усунути помилки, яких припустився в кадровій політиці й боротьбі з корупцією упродовж своєї каденції.

Натомість В. Зеленського увесь цей час критикували за закритість: він уникав прямого контакту 3 пресою й виборцями, обмежуючи спілкування короткими відеороликами, які завдяки епатажності й емоційності швидко поширювалися серед користувачів Інтернету. Комунікація з виборцями й опонентом відбувалася переважно через представників штабу.

Вагомим чинником у зростанні рейтингу цього кандидата став виклик політичному істеблішменту країни. Його широка популярність забезпечується правильним і влучним контентом, який подає власник сторінки (чи його команда) в мережі. Команда В. Зеленського вміло грає на електоральних настроях, запитах виборця, який ототожнюється переважно 3 простими людьми (у роликах та виступах простежується тактика ототожнення себе 3 цією категорією виборців - я людина проста), тому й звертається до аудиторії відповідною дохідливою мовою. Наприклад, просторічне звертання парни (рос.), яке він використовує в кількох інтерв'ю і яке не вписується у звичний офіційно-діловий тон публічних виступів.

Брак ораторського досвіду зумовлює використання невиправданих повторів: "У всіх цุих об'єднаних ігор є позитивна мета. Я думаю, щзо у АМІКа була позитивна мета - об'єднання"; "Тому щзо була інформаційна війна, дуже складна, однозначно. Була інформаційна війна" (інтерв'ю РБК-Україна від 18.04.2019 p.). 
Найактивніше обидва політики послуговуються стратегією "гра на зниження", яка реалізується через використання низки комунікативних тактик. Наприклад, тактика аналіз-"мінус". Одна $з$ найуживаніших в арсеналі В. Зеленського. У своїх промовах він представляє наявну ситуацію, спираючись на достовірні факти, і висловлює негативне ставлення до описуваного і до людей, які пов'язані з аналізованою подією, їхній дій та вчинків. Наприклад, засуджує свого опонента: "С Свинарчуки і так далі, які грабували нашу армію, піднімали собі гроші на крові хлопців" (інтерв’ю РБК-Україна від 18.04.2019 р.). Констатуючи факти, аргументи, які так чи так демаскують чиюсь злочинність, вину, політик використовує тактику викриття. Набуває слави "політичного кілера", який нещадно критикує свого опонента та стару політичну систему.

Особливістю політичного мовлення $\epsilon$ наявність адресата-спостерігача, на якого спрямовані комунікативні дії. Саме це сприяє реалізації стратегії театральності, яка представлена в мовленні В. Зеленського і здійснюється за допомогою низки тактик. Наприклад, викриваючи негативні сторони свого опонента, він спонукає його до конкретних дій, до прийняття інших, інколи протилежних поглядів. Це забезпечується тактикою підбурювання, наприклад: "Я даю Вам 24 години. Думай-те!".

П. Порошенко, маючи за плечима тривали політичний досвід, легко оперує значними обсягами інформації, тому активно використовує у виступах практичну аргументацію, це забезпечується тактикою інформування про конкретні дані та факти, які не передбачають особистісних думок і емоцій мовця до них.

Тактика обіиянки дуже рідко простежується в промовах В. Зеленського, він намагається завуальовано подати свої наміри (пор.: вже згадані гасла "Все буде Зе!иибісь!", "Ні обіиянок, ні пробачень"), що відкриває широке поле для домислів з боку потенційних виборців, можливість індивідуального "прочитання" й наповнення особистісними сенсами подібних висловлень.

Досить небезпечною в політичному мовленні може бути тактика провокації. I П. Порошенко, i В. Зеленський постійно підбурювали один одного до дій, вказуючи в той момент на недоліки особи й розраховуючи на відповідні наслідки. Наслідком таких комунікативних "інвестицій" було зростання рейтингу кожного з опонентів переважно у своєму сегменті виборців.

Не менш задіяною в побудові промов обох політиків є стратегія "гра на підвищення", яка відображає мотиви претендентів збільшити значимість власного статусу на тлі опонента. Прагнення піднестися над суперником забезпечується різними тактиками. Наприклад, майже в кожному виступі реалізується тактика (само)презентації. Специфікою вираження цієї тактики є використання особових займенників, наприклад, в інтерв'ю РБК-Україна від 18.04.2019 р., яке тривало трошки більше години В. Зеленський ужив займенник $я$ понад 200 разів; П. Порошенко у півгодинній промові після оголошення результатів екзит-полу - понад 50 разів.

Як і кожен інший політик, обидва кандидати під час передвиборчих перегонів стають об'єктами критики, різноманітних викриттів і звинувачень у свій бік. Потрапляючи в такі ситуації, політичні діячі використовують тактику відведення критики, метою якої є надання доказів невинності, за допомогою яких можливо пояснити (виправдати) певні вчинки та дії. Часто це забезпечується шляхом переадресації провини до іншого, наприклад, висловлення П. Порошенка: "Ключ від війни лежить не у Порошенка 8 сейфi, а в Москві".

Висновки. Вибір комунікантом певної моделі поведінки із застосуванням вдало дібраних комунікативних стратегій і тактик забезпечує ефективне спілкування, яке допомагає політику досягти жаданої цілі. Проаналізувавши виступи лідерів передвиборчих перегонів, ми дійшли висновку, що найхарактернішою й найуживанішою в арсеналі обох політиків є стратегія "гра на зниження", активно використовуються стратегії театральності та "гра на підвищення".

Для цілеспрямованого ефективного впливу на електорат обидва кандидати упродовж усієї кампанії послуговувалися цілим арсеналом різноманітних мовних засобів. 3 огляду на агональний (зосереджений на суперництві та перемозі) тип взаємодії між суперниками, зумовлений форматом передвиборчої кампанії, у мовленні політиків велику роль відігравали експресивні мовні засоби, зокрема лексика, спрямована на приниження та образу адресата (тактика образи). Звинувачення, які звучали в бік кожного 3 опонентів, важко розцінювати як суто емоційні прояви, вони більше нагадують влучний і продуманий стиль поведінки, користуючись яким суперники намагаються, 3 одного боку, самоствердитися, а 3 іншого, - спровокувати чи й принизити опонента.

Перспективи в дослідженні комунікативних стратегій у політичному дискурсі пов'язуємо 3 дослідженням їхнього репертуару в ідіостилі провідних політиків, організацією тематичних конференцій для обговорення різноманітних аспектів порушеної проблеми.

\section{СПИСОК ВИКОРИСТАНИХ ДЖЕРЕЛ ТА ЛІТЕРАТУРИ}

1. Абрамович С. Д. Мовленнєва комунікація : [підручник] / С. Д. Абрамович, М. Ю. Чікарькова. - К. : Центр навчальної літератури, 2004. - 472 с.

2. Алексенко С. Ф. Особливості вираження експресивності комунікативно-прагматичної стратегії "гра на підвищення" в англійській політичній промові [Електронний ресурс] / С. Ф. Алексенко // Проблеми 
семантики, прагматики та когнітивної лінгвістики. - Вип. 27. - 2015. - С. 3-13. - Режим доступу : http://psptkl 2015 27 3.pdf.

3. Гон М. М. Мова політики у парламентських виборах 2012 року в Україні [Електронний ресурс] / М. М. Гон // Панорама політологічних студій. - 2012. - Вип. 9. - С. 116-123. - Режим доступу : http://nbuv.gov.ua/UJRN/Pps_2012_9_19.

4. Михальская А. К. Педагогическая риторика : история и теория / А. К. Михальская. - Москва : Академия, 1998. $-432 \mathrm{c}$.

5. Попович М. Бути людиною / М. Попович. - К. : Вид. дім "Києво-Могилянська академія", $2011 .-223$ с.

6. Семенюк О. А. Основи теорії мовної комунікації : [навчальний посібник] / О. А. Семенюк, В. Ю. Паращук. - К. : ВЦ "Академія", 2010. - 240 с.

7. Яшенкова О. В. Основи теорії мовної комунікації / О. В. Яшенкова. - К. : Видавничий центр "Академія", 2010. $-312 \mathrm{c}$.

\section{REFERENCES (TRANSLATED \& TRANSLITERATED)}

1. Abramovych S. D. Movlennieva komunikatsiia [Speech communication]: [pidruchnyk] / S. D. Abramovych, M. Yu. Chikarkova. - K. : Tsentr navchal'noi literatury, 2004. - 472 s.

2. Aleksenko S. F. Osoblyvosti vyrazhennia ekspresyvnosti komunikatyvno-prahmatychnoi stratehii "hra na pidvyshchennia" v anhliiskii politychnii promovi [Peculiar Feature of Expressing Communicative and "bull campaign" Pragmatic Strategy in the English Political Discourse] [Elektronnyi resurs] / S. F. Aleksenko // Problemy semantyky, prahmatyky ta kohnityvnoi linhvistyky [Problems of Semantics, Pragmatics and Cognitive Linguistics]. - Vyp. 27. - 2015. - S. 3-13. - Rezhym dostupu : http://psptkl_2015_27_3.pdf.

3. Hon M. M. Mova polityky u parlamentskykh vyborakh 2012 roku v Ukraini [Political Language in Parliamentary Elections in Ukraine in 2012] [Elektronnyi resurs] / M. M. Hon // Panorama politolohichnykh studii. - 2012. Vyp. 9. - S. 116-123. - Rezhym dostupu : http://nbuv.gov.ua/UJRN/Pps_2012_9_19.

4. Mykhalskaia A. K. Pedahohycheskaia rytoryka: istoriia i teoriia [Pedagogical Rhetoric: History and Theory] / A. K. Mykhalskaia. - Moskva : Akademyia, 1998. - 432 s.

5. Popovych M. Buty liudynoiu [Being a Human] / M. Popovych. - K. : Vyd. dim "Kyievo-Mohylianska akademiia", 2011. $-223 \mathrm{~s}$.

6. Semeniuk O. A. Osnovy teorii movnoi komunikatsii : [navchal'nyi posibnyk] [Fundamentals of Theory of Language Communication] / O. A. Semeniuk, V. Yu. Parashchuk. - K. : VTs "Akademiia", 2010. - 240 s.

7. Iashenkova O. V. Osnovy teorii movnoi komunikatsii [Fundamentals of Theory of Language Communication] / O. V. Yashenkova. - K. : Vydavnychyi tsentr "Akademiia", 2010. - $312 \mathrm{~s}$.

\section{Дьяченко Н. Н., Халин В. В. Коммуникативные стратегии в современном украинском политическом дискурсе.}

В статье представлен материал о коммуникативных стратегиях современного украинского политического дискурса (на примере политической риторики кандидатов на должность Президента Украины П. Порошенко и В. Зеленского). В частности рассмотрена сущность понятия "политический дискурс" в коммуникативной лингвистике, охарактеризованы основные коммуникативные стратегии и тактики политического дискурса, а также специфика использования языковых средств, которые $в$ совокупности обеспечивают воплощение избранных коммуникативных стратегий и тактик в речах политиков.

Ключевые слова: политический дискурс, коммуникативная стратегия, коммуникативная тактика, П. Порошенко, В. Зеленский.

\section{Dyachenko N. N, Khalin V. V. Communicative Strategies in Modern Ukrainian Political Discourse.}

Political discourse reflects social and political life in the country, as well as, elements of its culture, general, specifically national and institutional values. The topicality of the present research is determined by the necessity of overall thorough analysis of modern political discourse, viz. on the level of studying idiostyle among political leaders and their communicative and strategic potential.

The research material is political rhetoric of candidates aspiring for a post of President of Ukraine, i.e. P. Poroshenko and V. Zelenskyi.

In the course of the studies we used general scientific methods (generalization, observation), genuinely linguistics methods (descriptive and a discourse analysis method), as well as, a continuous sampling method, a classification method and a method of cognitive interpretation.

The article presents communicative strategies of modern Ukrainian political discourse (on the example of political rhetoric of candidates aspiring for a post of President of Ukraine, i.e. P. Poroshenko and V. Zelenskyi). It highlights the essence of "political discourse" as a notion in communicative linguistics, characterizes major communicative strategies and political discourse tactics, and also specific features of using language means, which provide the implementation of the selected communicative strategies and tactics in political speeches. 
Analyzing speeches of the leaders in the election campaign, we concluded that the most characteristic and widely-spread strategy of both politicians is "bear campaign", they also actively employ theatrical strategies and "bull campaign" strategy.

To seek their goals and effectively influence the electorate both candidates use the entire toolkit of various language means in the course of their campaigns. Taking into account agonal (concentrated on competition and victory) type of competitors' interplay determined by the election campaign format, the speech of politicians was predominated by expressive language means, viz. lexicon aimed at humiliating and offending the addressee

(offense tactics). Accusations employed towards the opponent are difficult to estimate as purely emotional manifestations, they are more likely to remind a direct and well-thought behavioral style, implementing which, the opponents try, on the one hand, to assert themselves, and, on the other hand, to provoke and humiliate the opponent.

Key words: political discourse communicative strategy, communicate tactics, P. Poroshenko, V. Zelenskyi. 